\title{
PENTINGNYA PERAWAT BERPIKIR KRITIS PADA PENGAMBILAN KEPUTUSAN DI RUMAH SAKIT
}

\author{
WANDA MIFTAH FATIHAH
}

Email : wandamiftah22@gmail.com

\begin{abstract}
ABSTRAK
Latar Belakang: Berpikir kritis saat ini dianggap sebagai komponen penting dari perawat profesional. Berpikir kritis bertujuan untuk pertimbangan dalam pengambilan keputusan klinis. Dengan menekankan pentingnya berpikir kritis dan pengetahuan, dapat berpengaruh pada kualitas perawatan yang diberikan sehingga dapat menciptakan perkembangan kesehatan pasien dan memberikan keputusan yang terbaik sesuai kebutuhan pasien.

Metode: Metode yang dilakukan pada kajian ini yaitu Literature review, dengan menganalisis, serta mengekplorasi dan membaca buku dari referensi yang berbeda, dan juga di lengkapin dengan e-journal dan $e$-book yang mendukung dan relevan dengan judul kajian ini.

Hasil: Berdasarkan dilakukan literature review 1dapat disimpukan bahwa berpikir kritis sangat diharapkan dan dilaksanakan pada perawat untuk mendapatkan sebuah informasi sehingga proses keperawatan dapat berjalan dengan baik atau dengan semestinya.

Kesimpulan: Hasil dari pengkajian yang dilakukan secara literature review ini, diharapkan untuk seluruh mahasiswa keperawatan dapat mempelajari dan melaksanakan model berpikir kritis sehingga dapat di aplikasikan di rumah sakit pada proses dan asuhan keperawatan.
\end{abstract}

Kata kunci : Berpikir kritis, pengambilan keputusan, pentingnya berpikir kritis, perawat 


\section{Latar Belakang}

Berpikir kritis merupakan hal yang sangat penting bagi setiap orang. berpikir kritis sudah menjadi keterampilan yang penting, tak hanya perawat, seorang pengusaha, peneliti, bahkan mahasiswa pun seharusnya memiliki keterampilan tersebut. Seseorang yang berpikir kritis akan memiliki kemampuan dan keterampilan yang tinggi didalam komunikasi,dan dapat menentukan keputusan yang tepat.

Mahasiswa yang melaksanakan model berpikir kritis akan melakukan banyak strategi pemecahan masalah jika ia mendapatkan kesulitan.

Perawat juga harus melakukan dan mengaplikasikan berpikir kritis. Berfikir kritis penting dilakukan sebelum mengambil keputusan dalam asuhan keperawatan karena merupakan salah satu metode ilmiah dalam menyelesaikan masalah klien. Kemampuan perawat mengidentifikasi masalah klien dan memilih solusi intervensi yang tepat tidak lepas dari kemampuan perawat berfikir kritis untuk mengali berbagai alasan berdasarkan evidence base dari setiap problem dan solusi yang teridentifikasi (Potter\& Perry, 2010).

Pentingnya keterampilan berpikir kritis perawat untuk mengembangkan kemampuan pengambilan keputusan klinis telah diakui dengan baik dan menghasilkan upaya di seluruh dunia untuk menggabungkan elemen berpikir kritis dalam kurikulum keperawatan (Fowler 1998, Simpson \& Courtney 2002, Yu et al. 2013).

\section{Metode}

Metode yang dilakukan pada kajian ini yaitu Literature review, dengan menganalisis, menganalisis serta mengekplorasi dan membaca buku dari referensi yang berbeda, dan juga di lengkapin dengan $e$-journal dan $e$ book yang mendukung dan relevan dengan judul kajian ini.

\section{Hasil}

Berpikir kritis merupakan hal yang sangat penting pada pengambilan keputusan keputusan agar tindakan keperawatan yang dilaksanakan pada klien dapar berjalan dengan baik. 


\section{Pembahasan}

Dalam melakukan asuhan keperawatan merupakan kegiatan kompleks yang menuntut perawat untum memiliki keterampilan kognitif, psikomotor dan afektif untuk menilai intuitive dan kreatifitas. Dalam melakukan asuhan keperawatan, perawat akan menghadapi bermacam-macam situasi klinis sehingga perawat harus mampu berfikir kritis dalam setiap situasi yang dihadapinya untuk mampu membuat keputusan yang tepat dan akurat terhadap asuhan keperawatan yang dilakukan kepada klien.

Teori Ignatavicius \& Workman (2006) juga mengungkapkan bahwa berfikir kritis merupakan kompetensi yang perlu dimiliki oleh perawat agar dapat memberikan asuhan keperawatan yang berkualitas karena berfikir kritis sangat berkaitan dengan pengambilan keputusan dan penilaian klinis yang tepat.

Perawat yang mengaplikasikan berpikir kritis akan mampu bertindak secara sistematis, dan selalu menggunakan alasan yang rasional/ masuk akal.
Perawat yang mengaplikasikan model berpikir kritis seiring menggunakan pengetahuannya dari berbagai hal akan menciptakan suatu daya pikir dan solusi yang tepat saat menentukan pengambilan keputusan di rumah sakit dan perawat yang berpikir kritis akan langsung berinteraksi perihal keputusan yang akan ia laksanakan.

Brunt (2005), didefinisikan berpikir kritis dalam konteks praktik keperawatan sebagai proses pemikiran yang disengaja dan penalaran reflektif di mana praktisi memeriksa ide, asumsi, prinsip, kesimpulan, keyakinan, dan tindakan. Sementara banyak definisi yang dilaporkan dalam literatur, ada umum bahwa pemikiran kritis adalah pemikiran yang bertujuan yang melibatkan penalaran reflektif sebelum untuk memperoleh kesimpulan, yang mengarah pada keputusan klinis.

Perawat yang menerapkan atau mengaplikasikan berpikir kritis di dalam tiap mengambil keputusan terkait masalah dan kebutuhan pasien agar memberikan asuhan keperawatan yang bermutu. 
Asuhan keperawatan yang bermutu merupakan tujuan utama perawat di semua praktik pelayanan keperawatan yang disebut "great nursing". Great nursing adalah suatu konsep yang sulit didefinisikan secara sederhana, tetapi pada prinsipnya adalah aktivitas pelayanan perawatan untuk menjadi lebih baik.

Sebagai contoh, dari hasil pengkajian perawat mendapatkan hasil data klien yaitu tingginya demam $\left(40^{\circ}\right)$, keluhan sakit kepala dan nyeri otot serta adanya bintik kemerahan pada permukaan kulit. Perawat yang berpikir kritis akan melaksanakan keputusan dengan pengetahuan yang ia miliki. Perawat tersebut akan menganalisis untuk mendapatkan kesimpulan tentang apa yang dikeluhkan klien dan manifestasi klinik tersebut. Dengan demikian pernyataan, dan pengujian secara mendalam terkait masalah tersebut, pengumpulan data dan membuat kesimpulan serta cara berpikir kritis yang di aplikasikan perawat akan menghasilkan problem solving pengambilan keputusan yang baik dan akurat untuk memecahkan masalah yang dialami klien.
Menurut Deswani (2009), karakteristik berpikir kritis dalam keperawatan pada prinsipnya merupakan suatu kesatuan dari berpikir, merasakan dan melakukan . Mengingat profesi keperawatan merupakan profesi yang langsung berhadapan dengan nyawa, maka dalam melaksanakan tugasnya, perawat menggunakan perpaduan antara berpikir, merasakan dan melakukan secara komprehensif dan bersinegri. Perawat menerapkan keterampilan berpikir dengan menggunakan pengetahuan dari berbagai subjek dan lingkungannya, menangani perubahan yang berasal dari stresor lingkungan, dan membuat keputusan penting (Terry, 2013).

Berikut bagian dari model berpikir kritis dalam keperawatan :

Pertama, adanya kompetensi yang harus dimiliki. Kompetensi adalah tindakan cerdas serta tanggung jawab yang dimiliki perawat. Dengan kompetensi perawat akan mampu melaksanakan tugasnya dengan baik.

Kedua, adanya pengalaman. Pengalaman juga tidak kalah penting. Bukan hanya perawat yang sudah 
professional,mahasiswa keperawatan juga harus memiliki pengalaman. Mahasiswa yang sudah punya pengalaman dinas dirumah sakit akan bisa menilai sesuatu yang mungkin harus diperbaiki kedepannya seiring mengaplikasikan berpikir kritis.

Ketiga, adanya pengetahuan dasar yang dimiliki perawat. Perawat yang mendapatkan informasi dari suatu ilmu seperti lmu kemanusiaan dan ilmu-ilmu keperawatan dasar yang didapatkan saat berada di jenjang pendidikan yang diikuti.

Penerapan berpikir kritis pada proses keperawatan :

\section{Berpikir kritis pada diagnosa}

keperawatan, dilakukannya analisis dan mengelompokkan data secara objektif dan subjektif, serta mengetahui data normal. Dilakukan identifikasi masalah sesuai dengan data dan etiologimya.

\section{Berpikir kritis pada perencanaan} atau biasa disebut dengan intervensi. Dilakukan penyusunan rencana tindakan keperawatan yang akan dilaksanakan sesuai dengan kebutuhan klien. Dalam tahap ini harus dipertimbangkan dengan baik mengapa dan tindakan apa yang dilakukan, kapan dan siapa yang melakukan tindakan tersebut, serta bagaimana tindakan tersebut dilakukan.

Berpikir kritis pada tahap implementasi, pada tahap ini pelaksanaan rencana tindakan yang telah di tentukan dengan tujuan untuk memenuhi kebutuhan klien dilakukan dengan maksimal dan optimal.

Berpikir kritis pada tahap evaluasi, pada tahap ini proses penilaian pencapaian tujuan dan pengkajian ulang rencana keperawatan. Ditahap ini sebegai perawat harus menganalisis apakah pengambilan keputusan tercapai tujuan atau tidak.

\section{PENUTUP}

\section{KESIMPULAN}

Berpikir kritis adalah komponen yang sangat dibutuhkan oleh perawat agar menjadi perawat yang terampil, kompeten dan professional. Jika perawat dapat mengaplikasikan berpikir kritis diiringi dengan pengetahuan dan kreativitas, pengambilan keputusan terkait 
keperawatan klien akan mampu mendapatkan solusi sesuai dengan kebutuhan, dan dapat meningkatkan kualitas mutu asuhan keperawatan yang kompeten.

\section{SARAN}

Agar perawat dapat mengaplikasikan berpikir kritis, diharapkan untuk memperluas pengetahuan dan keterampilan dari berbagai subjek.

\section{DAFTAR PUSTAKA}

Fathi, A., \& Simamora, R.H. (2019). Investigating Nurses' Coping Strategies in Their Workplace as in Indicator of Quality of Nurses' Life in Indonesia: A Preliminary Study. In Iop Conference Series: Earth and Environmental Science . 248(1)

Kiki, D., Riri, A., \& Tini, S (2018). Pengaruh Berpikir Kritis Terhadap Kemampuan Perawat Pelaksana Dalam Melakukan Asuhan Keperawatan di Rumah Sakit Hermina Bekasi Tahun 2016. Jurnal Kesehatan Holistik. The Journal of Holistic Healthcare, Volume 12(1), Januari 2018, 21-25

Lamrani, m. H., Alammar, k. A., Alqahtani, s. S., \& Salem, o. A. (2018). Comparing the Effects of Simulation-Based and Traditional
Teaching Methods on the Critical Thinking Abilities and SelfConfidence of Nursing Students. Journal of Nursing Research, 26(3), 152-157.

Lee, D. S., Abdullah, K. L., Subramanian, P., Bachmann, R. T., \& Ong, S. L. (2017). An Integrated Review of The Correlation Between Critical Thinking Ability and Clinical Decision-making in Nursing. Journal of Clinical Nursing, 26(2324), 4065-4079.

Riegel, F., Crossetti, M. da G. O., \& Siqueira, D. S. (2018). Contributions of Jean Watson's Theory to Holistic Critical Thinking of Nurses. Revista Brasileira de Enfermagem, 71(4), 2072-2076

Shoulders, B., Follett, C., \& Eason, J. (2014). Enhancing Critical Thinking in Clinical Practice. Dimensions of Critical Care Nursing, 33(4), 207214.

Simamora, R. H. (2019). Menjadi Perawat yang: CIH'HUY. Surakarta: Kekata Publisher.

Syafei, I. (2015). Pengembangan Model Pembelajaran Untuk Meningkatkan Kemampuan Berpikir 
Kritis Siswa. Journal Ilmiah

Psikologi, Volume 2, 133-140

Tedjomuljo dan Afifah. (2016).

Tingkat Pengetahuan Mahasiswa

Keperawatan Tentang Kode Etik

Profesi dan Caring. Jurnal

Keperawatan Indonesia, 19(2),129-

136.

Terry, C.L., \& Weaver A. (2013).

Keperawatan Kritis. Edisi 1.

Yogyakarta: Rapha Publishing. 